\title{
Emergency Case of Failure in Spay Surgery
}

\section{Hazem Karem Shafik*}

Veterinary Surgeon, Salam Veterinary Group, Saudi Arabia

*Corresponding Author: Hazem Karem Shafik, Veterinary Surgeon, Salam Veterinary Group, Saudi Arabia.
Received: March 31, 2020

Published: April 30, 2020

(C) All rights are reserved by Hazem Karem

Shafik.

\section{Abstract}

A nine years old female cat had been operated a spay surgery due to pyometra but after a week it attempt to our clinic due to looking unwell and continuous moaning due to pain and the surgical suture had lost also the wound is not fine. Keywords: Spay Surgery; Pyometra

A nine years old female cat had been operated a spay surgery due to pyometra but after a week it attempt to our clinic due to looking unwell and continuous moaning due to pain and the surgical suture had lost also the wound is not fine.

So, after examination we found the following:

A. The external wound show necrosis and some of granulation tissue.

B. From the abdominal cavity:

1. Congestion in the descending colon.

2. Congestion in urinary bladder and necrosis in the dorsal aspect.

3. Omentum show necrosis, congestion and rotting.

4. Spleen enlarged and very dark in color and focal necrosis and the capsule show change in color.

5. The smelling of the abdominal cavity like a dead cadaver.

6. There are many blood clots and pus.

The process of surgery

1. Removal the remaining sutures and widen the wound.

2. Thoroughly wash the abdominal cavity by normal saline two time.

3. Then complete removal for the decayed omentum.

4. Removal of the necrotic tissue in the urinary bladder.

5. Debridement of the dead tissue in the wound.

6. Suturing the wound (simple interrupted).

\section{Post-surgical care}

1. Supportive treatment Ringer lactate (sodium lactate solution and hartmann's solution) and glucose 5\%.

2. Injection antibiotic (amoxicillin clavulanic acid dose $8.75 \mathrm{mg} /$ $\mathrm{kg} / 8 \mathrm{~h}$ ) for 5 days.

3. Dexamethasone $(.15 \mathrm{mg} / \mathrm{kg})$ for three days.

4. Multivitamins (vit B complex).

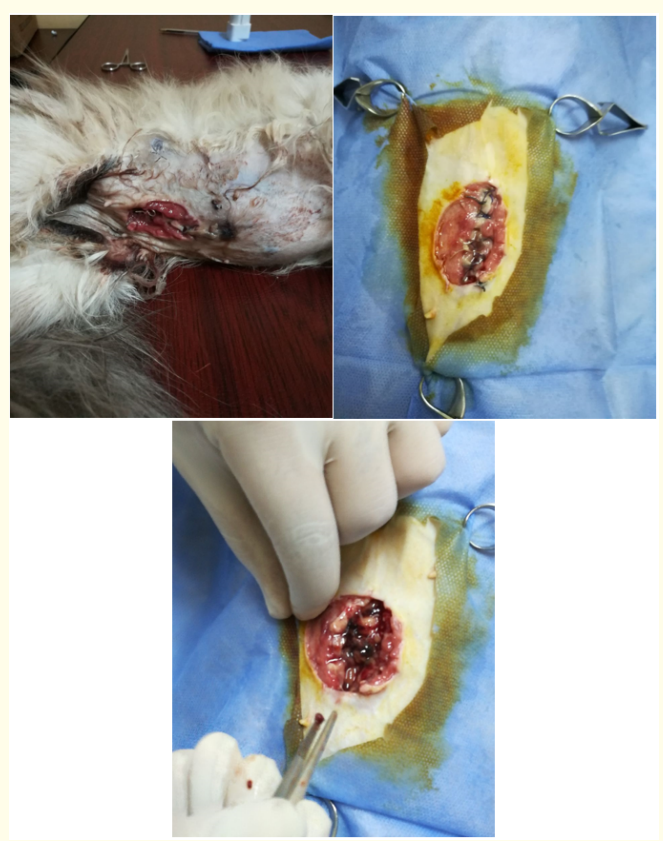

Figure 1: The external appearance of the wound. 


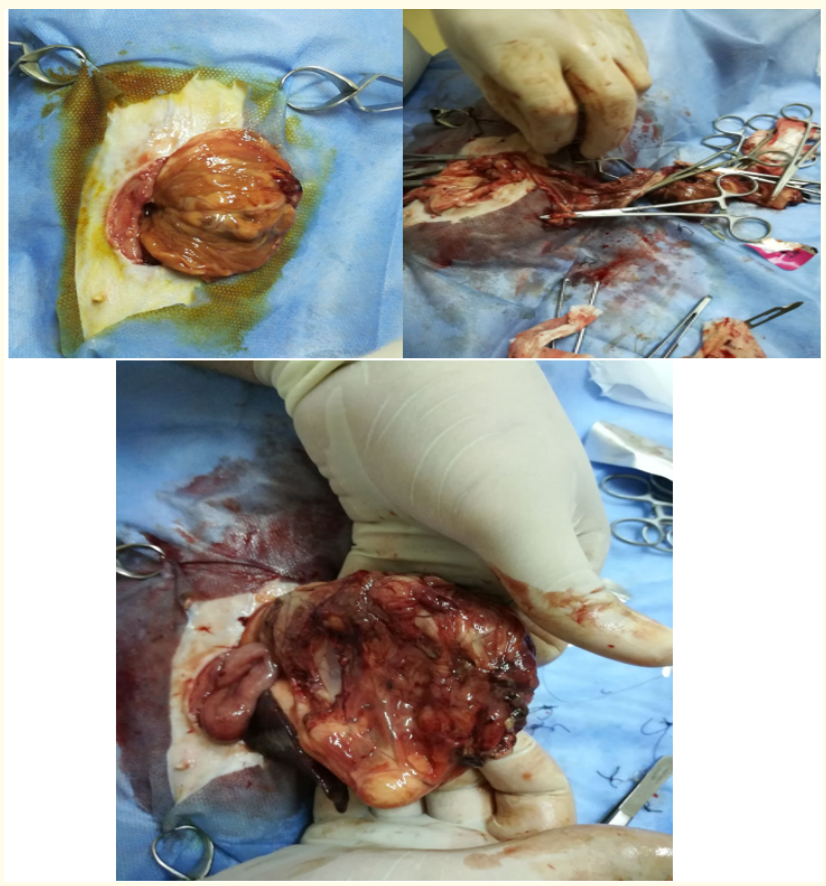

Figure 2: The omentum appearance.

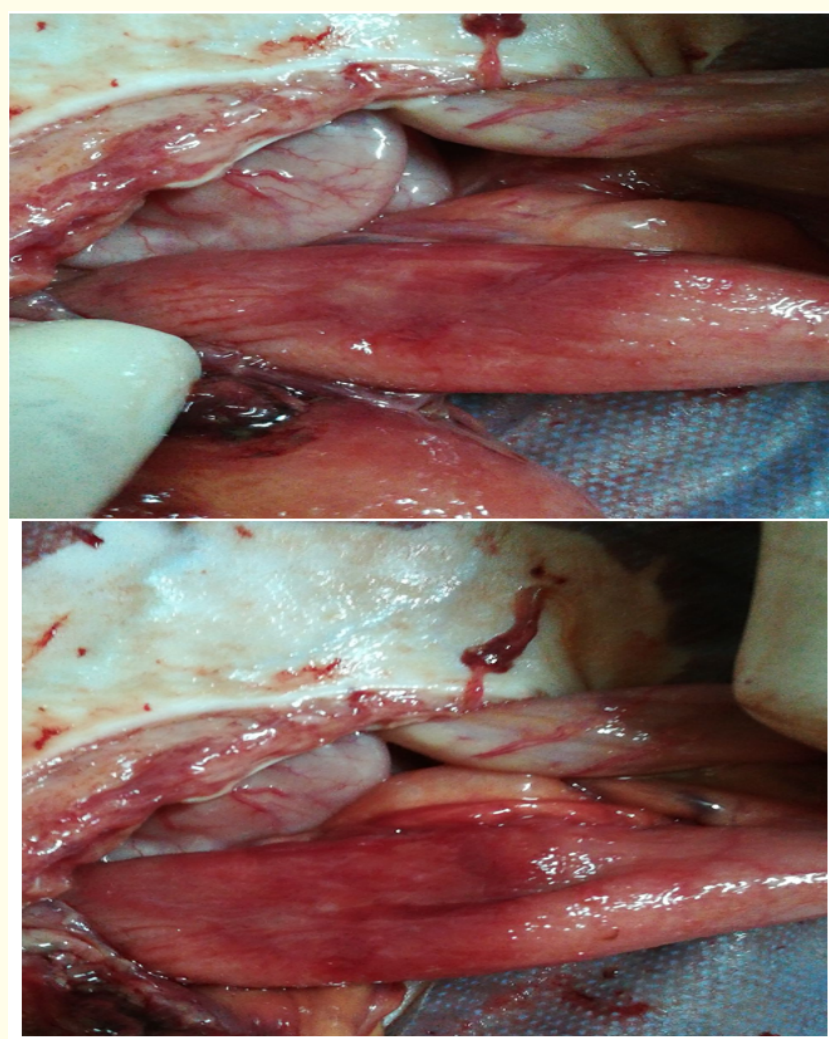

Figure 3: Congestion of descending colon

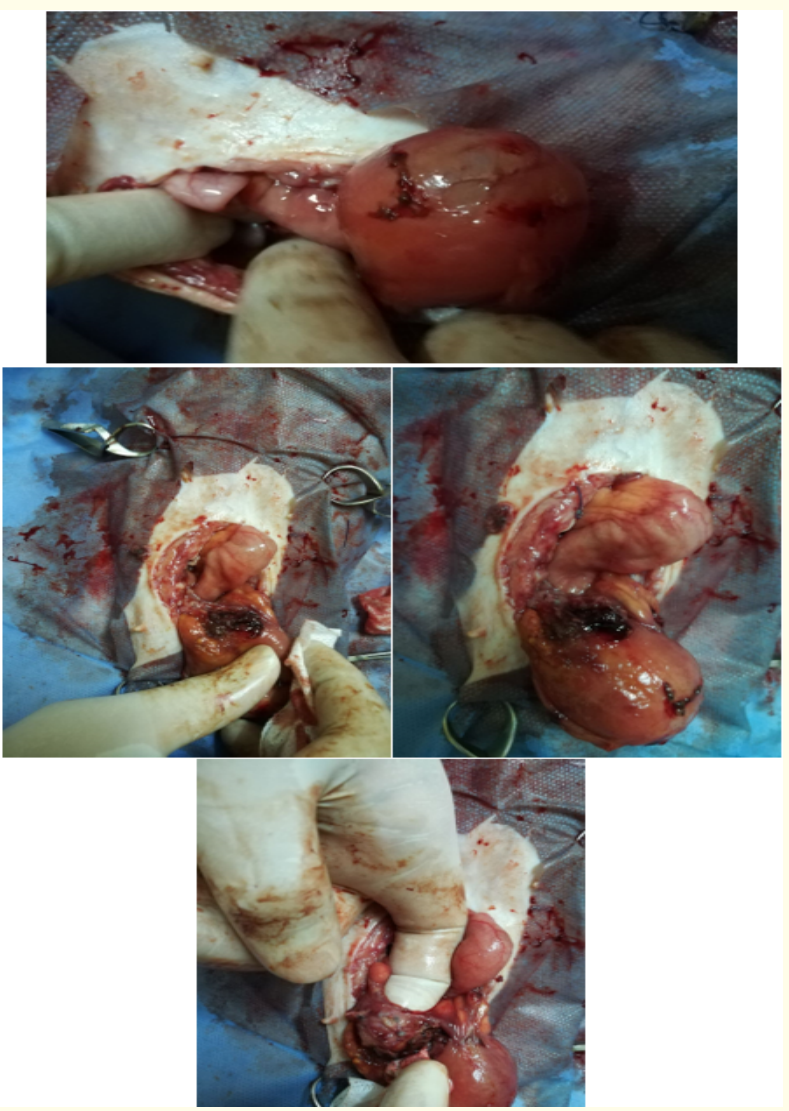

Figure 4: Congestion, necrosis and blood clot in urinary bladder.

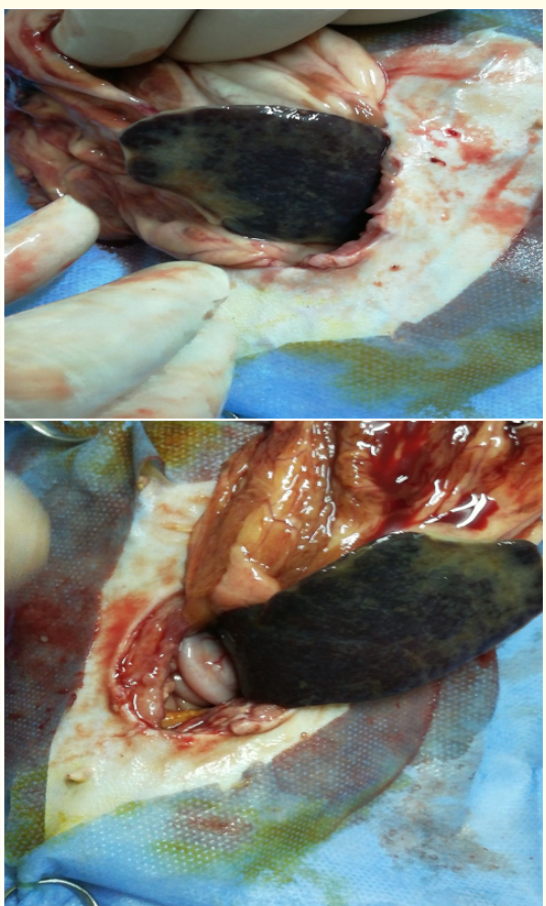

Figure 5: Spleen appearance. 


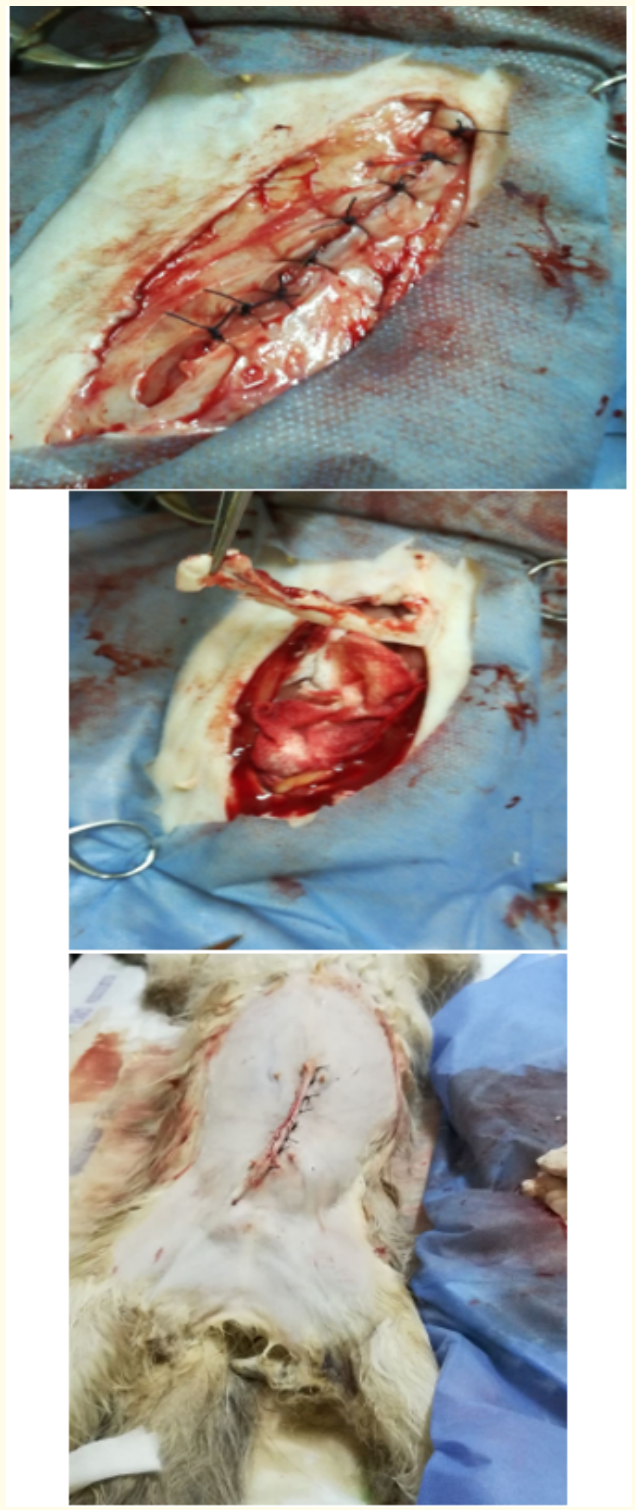

Figure 6: Debridement and suturing.

\section{Conclusion}

The failure in the first spay surgery due to the veterinarian left the uterus open without closure it by inverted suture so lead to leakage of the pus in the abdominal cavity so occur general infection affect all the internal organ by making congestion, necrosis and rotting so we had to remove the rotted parts and necrotic tissue as possible as we can, the uterus closed by fibrosis. 
Dental disease is the main oral disorder of horses and is of major importance in equine veterinary practice, with up to $10 \%$ of practice time involving dental-related work [1].

The purpose of the equine dental examination is to determine a pathologic condition exists and to evaluate its effect on condition of the horse's health [2].

It is important for the oral examination to be performed in a controlled environment to avoid potential distractions that could stimulate the horse [3].

It is impossible (and dangerous) to properly examine a horse's mouth without the use of a full mouth gag (speculum) [4].

Appropriate ambient lighting is necessary, and good-quality intraoral illumination is essential to enable a thorough oral examination without causing clinician eye strain and fatigue $[5,6]$.

Equipment that satisfies and assists in the performance of a thorough oral examination includes adjustable halter and lead rope, dental halter (padded metal noseband) and rope, full-mouth speculum, light, bucket of dilute antiseptic, dose syringe, hand towel or paper towels, flexible fiber optic endoscope (if available) and timer [2].

Regular dental care will benefit the health and subsequent performance of the horse. Neglected dental care lead to colic which is the most common emergencies seen by equine practitioners $\mathrm{Na}$ tionwide $[7,8]$.

Dentistry should be scheduled every 4 to 6 months for those horses that have teeth with occlusal areas not in wear and for those that are expected to perform at a high level [2].

The clinical signs associated with dental diseases are losing weight, dribbling grain, obvious shewing abnormalities, signs of facial tenderness, accumulating of grass or hay between the buccal gingiva and the cheek teeth (quidding), foul breath, excessive whole grain particles in feces and may be complicated with swelling on the lower jaw, maxilla or face and fistula [2,9].

Palpation through the cheeks may reveal food pocket- ing or detect major dental irregularities (such as a missing tooth or a large overgrowth) of the rostral three to four upper CT. Even if no such abnormality was palpated, the

\begin{tabular}{|c|c|c|c|c|c|c|}
\hline $\begin{array}{c}\text { Type of } \\
\text { horse }\end{array}$ & \multicolumn{2}{|c|}{ Equestrian } & Riding & $\begin{array}{l}\text { Funeral } \\
\text { dragging }\end{array}$ & \multirow{2}{*}{\begin{tabular}{|c}
$\begin{array}{c}\text { Total } \\
\text { number }\end{array}$ \\
92 \\
\end{tabular}} & $\begin{array}{c}\text { Percentage } \\
\%\end{array}$ \\
\hline Number & \multicolumn{2}{|c|}{52} & 34 & 6 & & \\
\hline \multirow{2}{*}{ Sex } & M & $\mathrm{F}$ & \begin{tabular}{|l|l|}
$M$ & $F$ \\
\end{tabular} & M & & \\
\hline & 49 & 3 & \begin{tabular}{|l|l|}
13 & 21 \\
\end{tabular} & 6 & & \\
\hline \multicolumn{7}{|l|}{\begin{tabular}{|l|}
$\begin{array}{l}\text { Dental } \\
\text { affections }\end{array}$ \\
\end{tabular}} \\
\hline $\begin{array}{l}\text { Dental } \\
\text { tartar }\end{array}$ & \multicolumn{2}{|c|}{33} & 36 & 6 & 75 & $81.52 \%$ \\
\hline $\begin{array}{l}\text { Sharp } \\
\text { enamel } \\
\text { points }\end{array}$ & \multicolumn{2}{|c|}{18} & 18 & 3 & 39 & $42.39 \%$ \\
\hline $\begin{array}{l}\text { Dental } \\
\text { caries }\end{array}$ & \multicolumn{2}{|c|}{18} & 12 & 3 & 33 & $35.86 \%$ \\
\hline $\begin{array}{l}\text { Periodontal } \\
\text { disease }\end{array}$ & \multicolumn{2}{|c|}{12} & 6 & - & 18 & $19.57 \%$ \\
\hline $\begin{array}{l}\text { Rostral } \\
\text { hook }\end{array}$ & \multicolumn{2}{|c|}{6} & 6 & 3 & 15 & $16.30 \%$ \\
\hline Diastmata & \multicolumn{2}{|c|}{9} & 6 & - & 15 & $16.30 \%$ \\
\hline \begin{tabular}{|l|} 
Incisor \\
tooth \\
fracture \\
\end{tabular} & \multicolumn{2}{|c|}{3} & 3 & - & 6 & $6.52 \%$ \\
\hline $\begin{array}{l}\text { Parrot } \\
\text { mouth }\end{array}$ & \multicolumn{2}{|c|}{3} & - & - & 3 & $3.26 \%$ \\
\hline Bit seat & \multicolumn{2}{|c|}{3} & - & - & 3 & $3.26 \%$ \\
\hline \begin{tabular}{|l} 
Caudal \\
hook
\end{tabular} & \multicolumn{2}{|c|}{ - } & 3 & - & 3 & $3.26 \%$ \\
\hline $\begin{array}{l}\text { Canine } \\
\text { tooth } \\
\text { fracture }\end{array}$ & \multicolumn{2}{|c|}{-} & 1 & - & 1 & $1.087 \%$ \\
\hline
\end{tabular}

Table 1: Include groups of horses, number, sex, type of dental affections and their percentage.

presence of pain (i.e. the horse pulling away or flinching) $[10,11]$.

Incisors teeth affections are divided to congenital and acquired disorders. Congenital disorders are: over bite [11], under bite [2], retained deciduous incisors [12] and Supernumerary permanent

\footnotetext{
${ }^{13}$ Doxirobe gel: Its active principle is (Doxycycline hyclate 8.5\%), It is used locally and produced by Zoetis US.

${ }^{14}$ Pen\&Strep: Its active principle is (Penicillin, Streptomycin), It is used I/M by dosage of $1 \mathrm{mg} / 20 \mathrm{~kg}$ and produced by Norbook.

${ }^{15}$ finadyne: Its active principle is (Flunixin meglumine), It is used I/M or I/V by dosage of $1 \mathrm{ml} / 45 \mathrm{~kg} \mathrm{~b}$ w. and produced by Intervet/Schering-Plough Animal Health.
} 
incisors [13]. Acquired disorders are incisor fractures [13], incisor occlusal surface abnormalities [14] and incisor diastmata [15].

Canine teeth affections are divided to congenital and acquired disorders. Congenital disorders are impacted tooth [2]. Acquired disorders are dental calculus (tartar) and dental infection [16].

Wolf teeth was found unerupted rostral to the teeth are com-

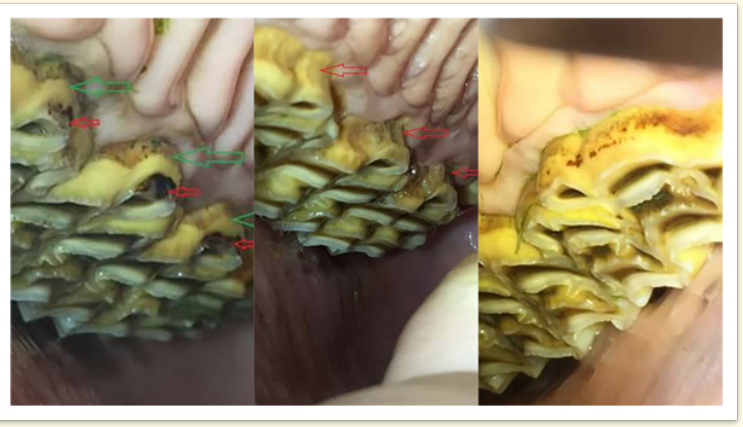

Figure 2: Shows dental tartar, dental decay and sharp enamel points, in cheek teeth (108 - 111) 4th pre- molar till third molar in riding horse, Female, 12 years old. After treatment: new healthy layer and decayed area is disappeared in "c image".
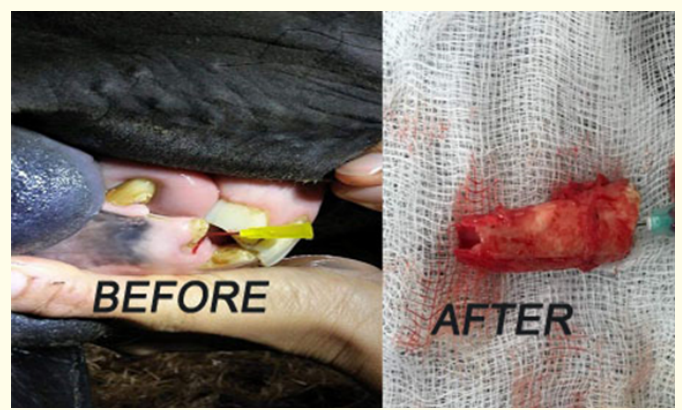

Figure 3: Shows a very painful pulp infection with fractured mandibular incisor (403) in young horse approximately 3 years, before and after treatment.

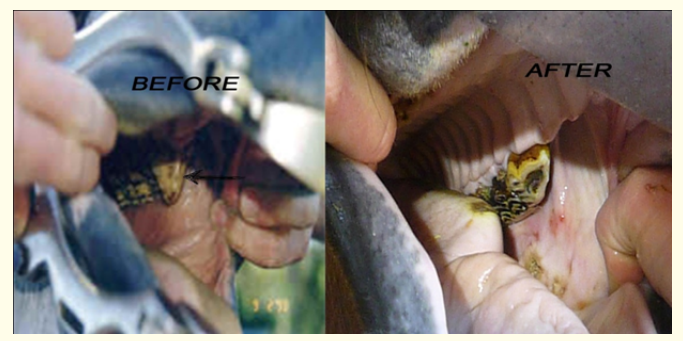

Figure 4: Shows rostral hook in (206) 2nd pre-molar in equestrian horse 13 years old, before and after treatment.

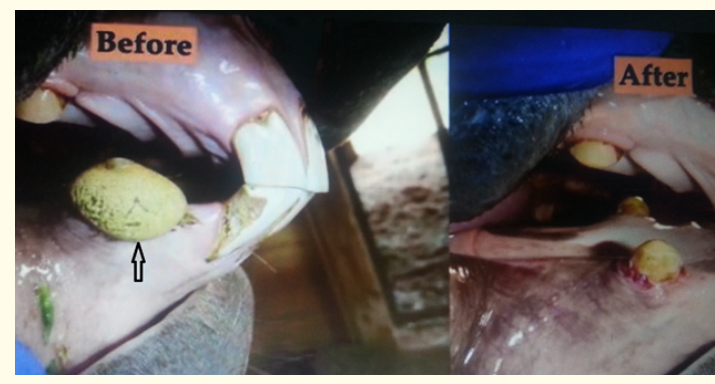

Figure 5: Shows tartar in lower right canine tooth (404) in riding horse, 12 years old, before and after treatment.

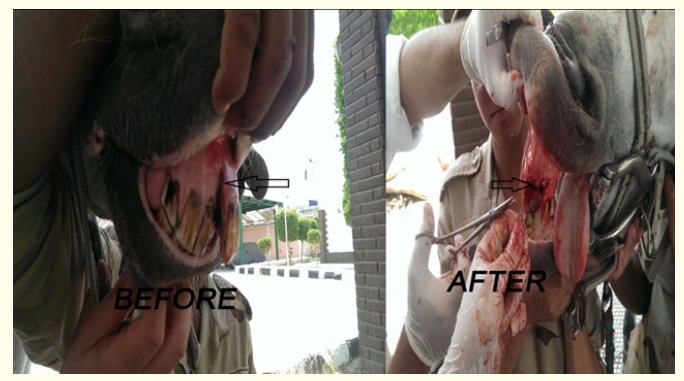

Figure 6: Shows fissure in gum because of hitting irony door of its stable and dental trauma in $(201,202)$ in equestrian horse, 13 years old, before and after treatment.

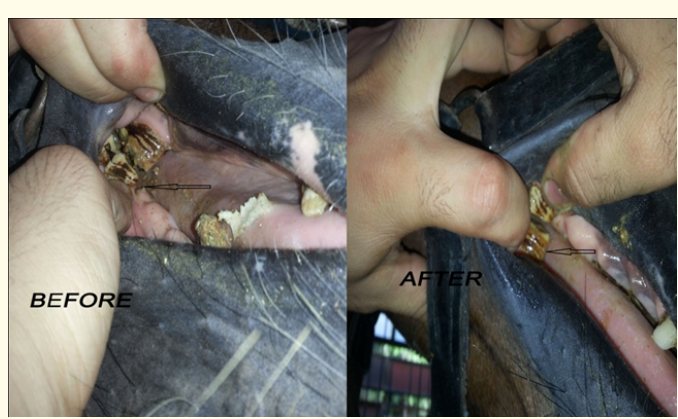

Figure 7: Shows (bit seat) and dental tartar in $(106,406) 2$ nd pre molar in equestrian horse, 11 years old, before and after treatment.

A

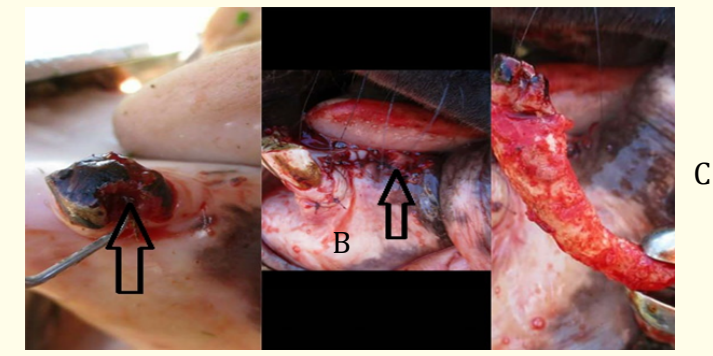

Figure 8: Shows fracture in lower left canine tooth (304) in riding horse, male, 12 years old. We extract this tooth by tooth extractor and suturing gum with absorbable sutures as in (B, C) images. 


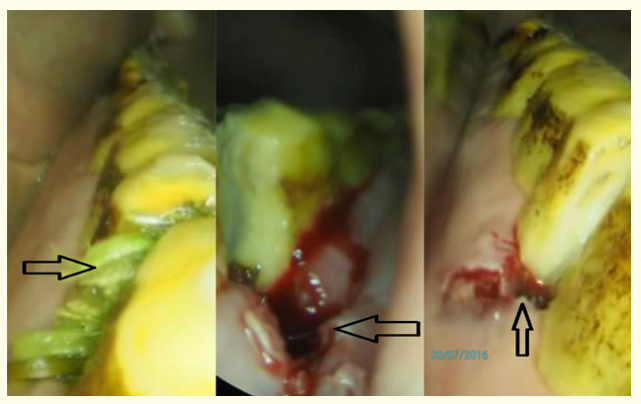

Figure 9: Shows diastmata and periodontal disease between "308-309" 4th pre molar till 3rd molar in equestrian horse, male 16 years old, before and after treatment.

monly referred to as blind wolf teeth [2].

Cheek teeth affections are divided to congenital disorders, abnormal position, disorder of wear and disease of cheek teeth. Congenital disorders are retained deciduous cheek teeth and supernumerary cheek teeth [16]. Abnormal position are rostral positioning of the upper cheek teeth, disparity in the length of the cheek teeth rows and diastema(ta) [17]. Disorders of wear are sharp enamel points, step mouth [16], smooth mouth [14], wave mouth and shear mouth [18], hooks (ramps) [19] and Bit seat [20]. Diseases of cheek teeth are Trauma [21], fracture, Periodontal disease, dental tumors [15], dental decay [22], dental plaque (tartar) [2] and dental foreign body [23].

Treatment of sharp enamel points, rostral hooks and caudal hooks involved reducing the overlong portion of the tooth by power float and dealing with bit seat by rounding and carefully smoothing rostral corners of the upper, lower \#6s help in good performance in bit [2].

Removal of overgrown transverse ridges opposite diastmata may reduce food impaction [24].

In case of tooth fracture needed to be extracted [15]

Treatment of periodontal disease by cleaning out periodontal pockets by dental picks, scaler and rinsing equipment and packing pockets with an antibiotic gel [2].

Management of dental caries by cleaning and filling these areas with a composite [2].

\section{Aim of the Work}

Aim is to investigate the dental affections in horses of eques- trian clubs and their possible treatment.

\section{Materials and Methods}

The present work was carried out in the period between "March 2015 to December 2016" the total number of examined horses was 354 horses, 92 horses had dental affections including 52 Equestrian horses, 34 Riding horses, 6 Funeral dragging horses. These horses were of both sexes and their ages were ranged between 3 years up to 22 years old. The examined horses were collected from Armed equestrian club, El Gzera club, El haram farms, Cairo stadium, El Shams club and Wadi Degla club.

The horses were divided according to usage into 3 groups, first group was used as equestrian horses, second group was used as riding horses and third group was used as funeral dragging horses. First group involved 52 equestrian horses, 49 male horses and 3 female ones. Second group involved 34 riding horses, 13 male horses and 21 female ones. Third group involved 6 funeral dragging horses, they all are male horses.

The examined horses in this study were subjected to comprehensive study including history, type of horse (Equestrian, Riding or Funeral dragging) the time of last floating, post treatment care and follow-up.

The history of each examined horse was obtained from its owner. The type, sex, age, time of last floating was recorded.

Equipment used in this study of a thorough oral examination and treatment includes lead rope, high power headlamp ${ }^{1}$, full mouth speculum ${ }^{2}$, bucket of dilute antiseptic (Betadine ${ }^{3}$ ), dose syringe, hand towel, tooth elevator ${ }^{4}$, tooth extractor ${ }^{2}$, power float ${ }^{2}$ and smart cam $^{5}$ (Figure 1). If the horse does not relax or at least tolerate the initial examination, we sedated the horse by (TranquiVed Xylazine $\mathrm{HCl}^{6}$ Injection or Sedivet $1 \%{ }^{7}$ ).

After care was consisted of injection of antibiotic that is against abroad spectrum of microbes streptopenicilline (pen\&strep ${ }^{8}$ ) at a dose of $1 \mathrm{mg} / 20 \mathrm{~kg}$ b.wt, I/M. for 3 days, injection of tetanus antitoxin $^{9}$ vaccine in single dose of $6000 \mathrm{IU} /$ horse by S/C, usage of betadine and allamycine spray ${ }^{10}$ locally in case of injuries and tooth extraction daily 3 times for a week, avoid feeding horse before 12 hours after application of anesthesia and the horses were observed for minimum a week post treatment.

\section{Results}

In the present study, total number of examined horses was 354 horses, 92 horses had dental affections by ratio about $26 \%$. The prevalent dental affections in horses of Egyptian equestrian clubs 
that were found are dental tartar, sharp enamel points, dental caries, rostral hook, periodontal disease, diastmata, incisor tooth fracture, parrot mouth, bit seat, caudal hook and canine tooth fracture.

In dental tartar represented 75 horses with percentage $81.52 \%$. Treatment involved removal of tartar with curetting the tooth with tooth elevator and disinfection with tincture iodine $2 \%{ }^{11}$ (Figure 2 and 5).

Sharp enamel points were found in 39 horses with percentage $42.39 \%$. Treatment involved teeth should be floated by power float in stages, e.g. at three to six monthly intervals to prevent pulpar exposure, Digitally loose teeth can be extracted orally using tooth extractor in standing sedated horses, thorough washing of the mouth with Betadine and make stab wound in the hematomed hard palate helps horse to eat well (Figure 2).

Dental caries were recorded in 33 horses with percentage $35.86 \%$. Treatment involved cleaning the tooth well by tooth elevator, rinsing it by water then by tincture iodine $2 \%$. Degenerated tooth material should be debrided, repeating hexitol ${ }^{12}$ mouthwashes are the best treatment of dental caries and decreasing the proportion of dietary simple carbohydrates (grains such as barley and oats) regresses the disease (Figure 2).

Periodontal disease was noticed in 18 horses with percentage $19.57 \%$. Treatment involved (Treat primary cause in case of secondary periodontal disease, cleaning out periodontal pockets, and packing pockets with an antibiotic gel (Doxirobe gel ${ }^{13}$ ). Wid-

\section{Bibliography}

1. BEVA. "British Equine Veterinary Association survey of equine disease". Veterinary Record 77 (1965): 528-538.

2. Pence P. "Equine Dentistry: A Practical Guide". Published by Lippincott Williams and Wilkins, $2^{\text {nd }}$ edition (2002).

3. Menzies RA., et al. "Essential considerations for equine oral examination, diagnosis, and treatment". Journal Veterinary Dentistry 28 (2011): 204-209.

4. Scrutchfield WL. "Dental prophylaxis". GJ Baker, J.Easley (Eds.), Equine Dentistry (first edition.), W.B. Saunders, London (1999): 185-205.

5. Young JM., et al. "Intraoral dental lights: test and evaluation". Journal of Prosthetic Dentistry 57.1 (1987): 99-107.

6. Preston JD., et al. "Light and lighting in the dental office". Dental Clinics of North America 22.3 (1978): 431-451.
7. Lowder MQ. "Floating teeth". Veterinary Record 77 (2001): 528-538.

8. Lowder MQ and Mueller POE. "Dental disease in geriatric horses". Veterinary Clinics of North America: Equine Practice (1998): 365-380.

9. O'Connor JJ. "Dollars Veterinary Surgery (second edition)". Balliere Tindall and Cox, London (1930): 481-491.

10. Scrutchfield WL and Schumacher J. "Examination of the oral cavity and routine dental care". Veterinary Clinics of North America - Equine Practice (1993): 123-131.

11. Easley J. "Dental and oral examination". GJ Baker, J Easley (Eds.), Equine Dentistry (first ed.), W.B. Saunders, London (1999): 107-126.

12. Alexander K., et al. "Incisor extraction in a horse by a longitudinal forage technique". Equine Veterinary Education (2001): 179-182.

13. Dixon PM., et al. "Equine dental disease part 1: a long-term study of 400 cases: disorders of incisor, canine and first premolar teeth". Equine Veterinary Journal (1999): 369-377.

14. Kempson SA., et al. "The effect of three types of rasps on the occlusal surface of equine CT: a scanning electron microscopic study". Journal of Veterinary Dentistry (2003): 19-27.

15. Dixon PM and Collins NM. "Diagnosis and management of equine diastmata". Clinical Techniques in Equine Practice 4.2 (2005): 148-154.

16. Dixon PM and Dacre I. "A review of equine dental disorders". The Veterinary Journal 169.2 (2005): 165-187.

17. Carmalt JL. "Understanding the equine diastema". Equine Veterinary Education (2003): 34-35.

18. Peter D., et al. "Merck Manual for Pet Health, Pet Owners, Horse Disorders and Diseases, Digestive Disorders of Horses" (2011).

19. Koontz RH. Chief Executive Officer, Conley and Koontz Equine Hospital (2016): 183.

20. Bettiol N and Dixon PM. "An anatomical study to evaluate the risk of pulpar exposure during mechanical widening of equine cheek teeth diastmata and 'bit seating'". Equine Veterinary Journal 43.2 (2011): 163-169. 
21. Dixon PM., et al. "Equine dental disease". Part 3: a long-term study of 400 cases: disorders of wear, traumatic damage and idiopathic fractures, tumours and miscellaneous disorders of the cheek teeth". Equine Veterinary Journal (2000a): 9-18.

22. Timothy AOO and Joseph FA. "Do dental abnormalities predispose horses to colic?" Journal of Veterinary Medicine and Animal Health 6.7 (2014): 192-197.

23. Saulez MN., et al. "Perforation of the gastrointestinal tracts of four horses by metallic wires". Veterinary Record 164 (2009): 86-88.

24. Barakzai SZ and Dixon PM. "A study of open-mouthed oblique radiographic projections for evaluating lesions of the erupted (clinical) crown". Equine Veterinary Education (2003): 143148.

25. Becker E., et al. "Handbook of special pathological anatomy of pets (third edition.)". Verlag Paul Parey Berlin (1962): 121133.

26. Brigham EJ and Duncanson G. "Case study of 100 horses presented to an equine dental technician in the UK". Equine Veterinary Education (2000b): 63-67.

27. Ramzan PH. "The need for chemical restraint while performing routine dental procedures using a full mouth speculum: a retrospective study of 581 examinations". Equine Veterinary Education (2002): 30-32.

28. Dixon PM., et al. "Equine dental disease part 4: a long-term study of 400 cases: apical infections of cheek teeth". Equine Veterinary Journal (2000b):182-194.

29. Dacre IT. "Equine dental pathology". In: Baker GJ, Easley J. (Editions.), Equine Dentistry, second edition. W.B. Saunders, London, in press (2004).

\section{Assets from publication with us}

- Prompt Acknowledgement after receiving the article

- Thorough Double blinded peer review

- Rapid Publication

- Issue of Publication Certificate

- High visibility of your Published work

Website: www.actascientific.com/

Submit Article: www.actascientific.com/submission.php

Email us: editor@actascientific.com

Contact us: +919182824667 